\title{
Fleas as parasites of the family Canidae
}

\author{
Gerhard Dobler ${ }^{1 *}$ and Martin Pfeffer ${ }^{2}$
}

\begin{abstract}
Historically, flea-borne diseases are among the most important medical diseases of humans. Plague and murine typhus are known for centuries while the last years brought some new flea-transmitted pathogens, like $R$. felis and Bartonella henselae. Dogs may play an essential or an accidental role in the natural transmission cycle of flea-borne pathogens. They support the growth of some of the pathogens or they serve as transport vehicles for infected fleas between their natural reservoirs and humans. More than 15 different flea species have been described in domestic dogs thus far. Several other species have been found to be associated with wild canids. Fleas found on dogs originate from rodents, birds, insectivores and from other Carnivora. Dogs therefore may serve as ideal bridging hosts for the introduction of flea-borne diseases from nature to home. In addition to their role as ectoparasites they cause nuisance for humans and animals and may be the cause for severe allergic reactions.
\end{abstract}

\section{Background}

Fleas (Order Siphonaptera) form a unique group of insects. They have evolved in the early Cretaceous or Jurassic ages between 125 to 150 million years ago, probably together with the evolution of marsupials and insectivors. Historically, fleas are among the most important ectoparasites of humans in that several species are the natural vectors of several important infectious diseases, like plague. Today, some 15 families with a total of about 220 genera and some 2,500 species of fleas can be distinguished [1].Out of these, five families and 25 genera are ectoparasites of birds, and all other fleas parasitize mammals. Most fleas of veterinary importance are grouped in the families Pulicidae, Ceratophyllidae, Leptopsyllidae and Vermipsyllidae. Rarely, members of other families (Hystrichopsyllidae, Rhopalopsyllidae) may be found on domestic animals. Besides domestic cats, dogs may play a peculiar role as bridging hosts for fleas of different wild animals, domestic animals and humans, as they will come into contact with different animals during their seeking behaviour and therefore acquire the fleas of different animals. Fleas may play different roles as parasites in mammals. They may act as vectors to transmit pathogens. They may play a role as intermediate hosts of parasites and can be

\footnotetext{
* Correspondence: gerharddobler@bundeswehr.org

'Bundeswehr Institute of Microbiology, Department of Virology and

Rickettsiology, Neuherbergstrasse 11, D-80937 Munich, Germany

Full list of author information is available at the end of the article
}

an ectoparasitic nuisance in animals and humans which may cause allergic reactions.

\section{Review}

\section{Morphology and Development}

Fleas are wingless, 1-8 $\mathrm{mm}$ in size with laterally compressed bodies composed of a blunt head, a compact thorax and a fairly large, rounded abdomen. The colour is usually dark brown. Small eyes may or may not be present. The bodies of adult fleas bear many spines which are used for species determination. Among them are the combs or ctenidia, a row of enlarged sclerotized spines on the head (genal ctenidium), which are always absent in fleas parasitizing birds, or on the prothorax (pronotal ctenidium) which may be present or absent.

Fleas develop from eggs to larvae (usually consisting of three instar generations) and pupae into the adult stage (Figure 1). Females lay up to 25 eggs per day and a total of several hundreds during their life. The speed of development is dependent on environmental conditions. Higher temperatures may increase the generation time of fleas. Colder temperatures and higher humidity influence the longevity of fleas in the absence of available hosts. Fleas of domestic animals oviposit their eggs randomly into the environment. The developing larvae feed on organic matter. In some flea species, like Ctenocephalides (C.) felis, the dried, blood-rich feces of adult fleas will be used for food by the larvae. Others may feed on small arthropods, if available in the surroundings or even use other larvae as food (cannibalism). The
C Biomed Central

(c) 2011 Dobler and Pfeffer; licensee BioMed Central Ltd. This is an Open Access article distributed under the terms of the Creative Commons Attribution License (http://creativecommons.org/licenses/by/2.0), which permits unrestricted use, distribution, and reproduction in any medium, provided the original work is properly cited. 


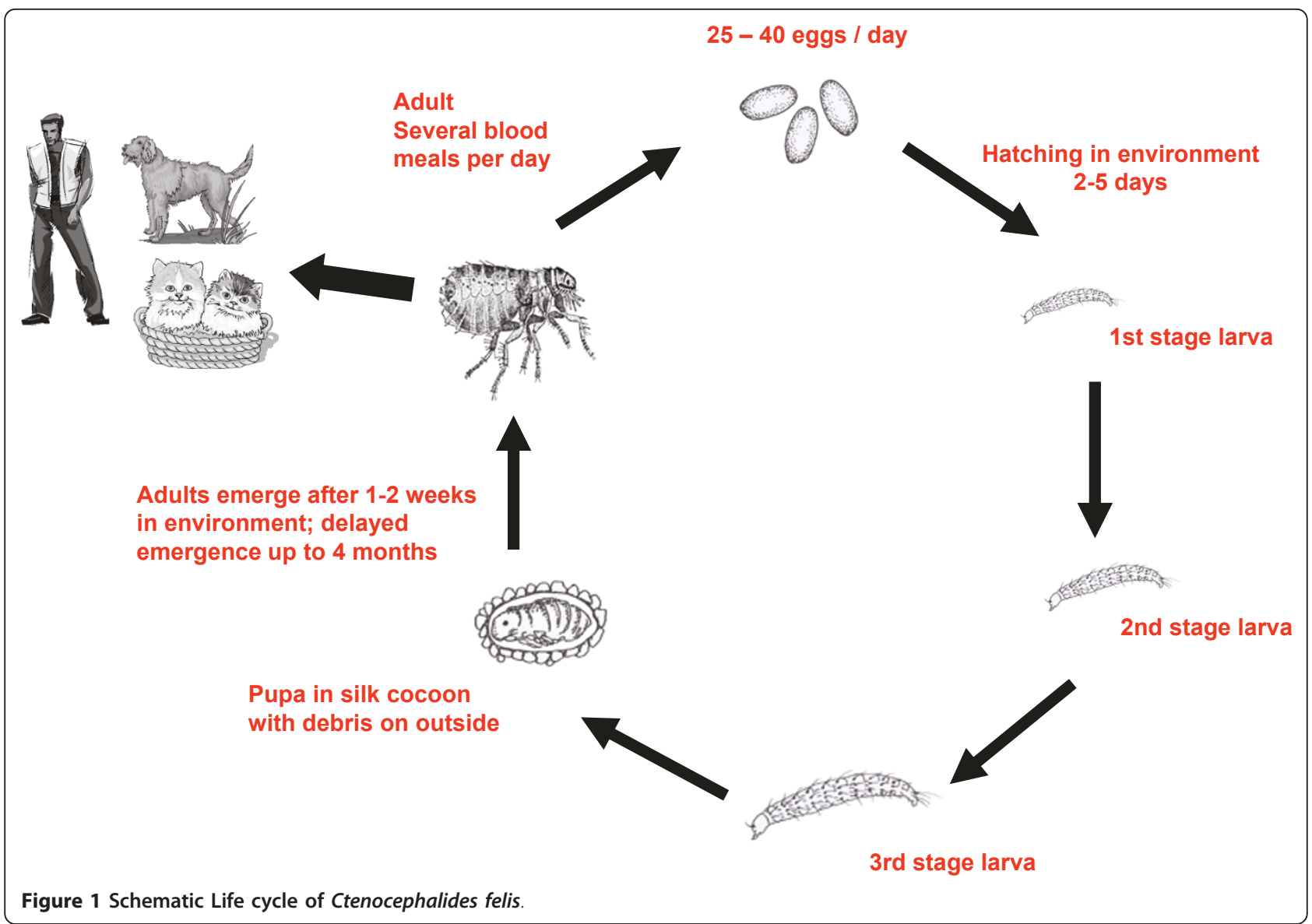

development through the three instar larval stages lasts about 2 to 3 weeks. The third instar larval stage spins a silk cocoon including dust, debris and grains of sand, which are bound together by silk and which act as camouflage for the pupa during development to adult stages. The adult flea emerges almost colourless, but melanisation starts immediately so that imagos darken within a short period of time. Adult fleas feed frequently several times during the day, which is necessary as most of the blood is excreted in a semi-digested stage and these flea feces may be frequently used as food by the larvae.

\section{Fleas of domestic dogs}

Fleas have a global distribution. As far as data are known from different countries worldwide, fleas are also found in dogs all over the world. To our best knowledge, no comprehensive review of the occurrence and frequency of fleas in dog populations is available. We therefore evaluated the published literature of the years 1980 to 2010 for occurance and frequency of fleas in the dog populations of the different countries (Table 1). This literature search provided evidence of at least 15 different species of fleas found on domestic dogs. The data show that the most prevalent flea species found globally in domestic dogs is the cat flea (C. felis, Figure 1). Prevalence rates range form $5 \%$ to $100 \%$. The dog flea (C. canis) also occurs globally, but in lower rates than the cat flea. The presence of the human flea, Pulex $(P$.) irritans, in many countries and on average on up to $10 \%$ of tested dogs may show evidence of the close contact between humans and dogs. Several other species of fleas, originally feeding on birds (hen fleas), rodents (rat fleas) or insectivores (hedgehog fleas) are found on domestic dogs which indicates that dogs due to their habits will come into contact with other domestic and wild animals and pick up fleas of these animals. This contact with other animals, together with the close contacts with humans on the other hand, predestine dogs as a bridging vector for ectoparasites from domestic or wild animals to humans and for the agents which they might transmit while blood-feeding.

Since the 1990s, many powerful anti-ectoparasitics for domestic animals were commercialized which can be easily applied by the animal owners. The use of these repellents may have changed the prevalence of flea infestation of domestic dogs, especially in developed countries where these substances are in use. 
Table 1 Prevalence of flea infestation in dog populations of various countries (according to different references) (A.: Archaeopsylla; C.: Ctenocephalides; Ca.: Cediopsylla; Cr.: Ceratopsyllus; Ct.: Ceratophyllus; E.: Echidnophaga; M.: Megabothris; P.: Pulex; Pa. Paraceras; R.: Rhopalopsyllus; T.: Tunga; X.: Xenopsylla; n.d. no data provided)

\begin{tabular}{|c|c|c|c|c|}
\hline Country & No. of dogs tested & Infestation rate (\% of tested dogs carrying fleas) & Flea species detected & Literature \\
\hline \multirow[t]{3}{*}{ Albania } & 181 & $76 \%$ & C. canis & [76] \\
\hline & & $\overline{5 \%}$ & C. felis & \\
\hline & & $\overline{8 \%}$ & P. irritans & \\
\hline Argentina & 116 & $98 \%$ & C. canis & [77] \\
\hline \multirow[t]{3}{*}{ Australia } & 116 & $85 \%$ & C. felis & [78] \\
\hline & & $6 \%$ & C. canis & \\
\hline & & $\overline{13 \%}$ & E. gallinacea & \\
\hline \multirow[t]{3}{*}{ Austria } & 129 & $81 \%$ & C. felis & [65] \\
\hline & & $\overline{19 \%}$ & C. canis & \\
\hline & & $7 \%$ & A. erinacei & \\
\hline Brazil & 61 & $69 \%$ & T. penetrans & [79] \\
\hline \multirow[t]{3}{*}{ Brazil } & 101 & $64 \%$ & C. felis & [80] \\
\hline & & $2 \%$ & Rh. lutzi & \\
\hline & & $2 \%$ & T. penetrans & \\
\hline$\overline{\text { Brazil }}$ & 41 & $44 \%$ & C. felis & [81] \\
\hline \multirow[t]{2}{*}{ Brazil } & 46 & $39 \%$ & C. canis & [82] \\
\hline & & $17 \%$ & C. felis & \\
\hline \multirow[t]{3}{*}{ Chile } & 3000 & $42 \%$ & C. felis & [83] \\
\hline & & $39 \%$ & C. canis & \\
\hline & & $19 \%$ & P. irritans & \\
\hline \multirow[t]{2}{*}{ Denmark } & 140 & $54 \%$ & C. felis & [84] \\
\hline & & $42 \%$ & C. canis & \\
\hline \multirow[t]{4}{*}{ France } & 392 & $89 \%$ & C. felis & [85] \\
\hline & & $10 \%$ & C. canis & \\
\hline & & $1.3 \%$ & A. erinaceus & \\
\hline & & $0.8 \%$ & P. irritans & \\
\hline \multirow[t]{8}{*}{ Germany } & 1922 & $4 \%$ & C. felis & [73] \\
\hline & & $0,9 \%$ & C. canis & \\
\hline & & $<0,1 \%$ & A. erinacei & \\
\hline & & $<0,1 \%$ & P. irritans & \\
\hline & & $<0,1 \%$ & Ce. gallinae & \\
\hline & & $<0,1 \%$ & Cr. garei & \\
\hline & & $<0,1 \%$ & Pa. melis & \\
\hline & & $<0,1 \%$ & M. sp. & \\
\hline \multirow[t]{4}{*}{ Germany } & 48 & $46 \%$ & C. felis & [86] \\
\hline & & $44 \%$ & C. canis & \\
\hline & & $19 \%$ & A. erinacei & \\
\hline & & $10 \%$ & P. irritans & \\
\hline \multirow[t]{3}{*}{ Germany } & 163 & $28 \%$ & C. felis & {$[87]$} \\
\hline & & $14 \%$ & C. canis & \\
\hline & & $58 \%$ & A. erinacei & \\
\hline \multirow[t]{4}{*}{ Greece } & 129 & $71 \%$ & C. canis & [74] \\
\hline & & $40 \%$ & C. felis & \\
\hline & & $1 \%$ & P. irritans & \\
\hline & & $1 \%$ & X. cheopis & \\
\hline
\end{tabular}


Table 1 Prevalence of flea infestation in dog populations of various countries (according to different references) (A.: Archaeopsylla; C.: Ctenocephalides; Ca.: Cediopsylla; Cr.: Ceratopsyllus; Ct.: Ceratophyllus; E.: Echidnophaga; M.: Megabothris; P.: Pulex; Pa. Paraceras; R.: Rhopalopsyllus; T.: Tunga; X.: Xenopsylla; n.d. no data provided) (Continued)

\begin{tabular}{|c|c|c|c|c|}
\hline \multirow[t]{3}{*}{ Hungary } & \multirow[t]{3}{*}{2267} & $8 \%$ & C. canis & \multirow[t]{3}{*}[72]{} \\
\hline & & $6 \%$ & C. Felis & \\
\hline & & $<0,1 \%$ & P. Irritans & \\
\hline \multirow[t]{5}{*}{ Iran } & \multirow[t]{5}{*}{756} & $8 \%$ & C. felis & \multirow[t]{5}{*}[88]{} \\
\hline & & $1 \%$ & C. Canis & \\
\hline & & $0,9 \%$ & P. irritans & \\
\hline & & $0,5 \%$ & X. cheopis & \\
\hline & & $0,3 \%$ & Ca. simplex & \\
\hline \multirow[t]{4}{*}{ Ireland } & \multirow[t]{4}{*}{103} & $75 \%$ & C. Felis & \multirow[t]{4}{*}{ [89] } \\
\hline & & $18 \%$ & C. canis & \\
\hline & & $4 \%$ & A. erinacei & \\
\hline & & $2 \%$ & Ca. spp. & \\
\hline \multirow[t]{2}{*}{ Italy } & \multirow[t]{2}{*}{1376} & $16 \%$ & C. felis & \multirow[t]{2}{*}{ [90] } \\
\hline & & $2 \%$ & C. canis & \\
\hline Korea, Republic of & 103 & 75 & C. canis & {$[91]$} \\
\hline \multirow[t]{3}{*}{ Laos } & \multirow[t]{3}{*}{3} & n.d. & C. felis & \multirow[t]{3}{*}[92]{} \\
\hline & & n.d. & C. canis & \\
\hline & & n.d. & C. orientis & \\
\hline \multirow[t]{2}{*}{ Mexico } & \multirow[t]{2}{*}{1803} & $25 \%$ & C. felis & \multirow[t]{2}{*}{ [93] } \\
\hline & & $5 \%$ & C. canis & \\
\hline New Caledonia & 8 & $100 \%$ & C. felis & [38] \\
\hline \multirow[t]{3}{*}{ Nigeria } & \multirow[t]{3}{*}{396} & $33 \%$ & C. canis & \multirow[t]{3}{*}{ [94] } \\
\hline & & $7 \%$ & P. irritans & \\
\hline & & $0,5 \%$ & T. penetrans & \\
\hline Pakistan & n.d. & $34 \%$ & C. felis & {$[95]$} \\
\hline Poland & 50 & $100 \%$ & C. canis & {$[96]$} \\
\hline \multirow[t]{4}{*}{ Spain } & 109 & $100 \%$ & P. irritans & [97] \\
\hline & \multirow[t]{3}{*}{87} & $71 \%$ & C. felis & \multirow[t]{3}{*}{ [98] } \\
\hline & & $13 \%$ & C. canis & \\
\hline & & $16 \%$ & P. irritans & \\
\hline Spain & 744 & $95 \%$ & C. felis & [99] \\
\hline & & $10 \%$ & C. canis & \\
\hline & & $1 \%$ & P. irritans & \\
\hline & & $0,1 \%$ & E. gallinacea & \\
\hline United Kingdom & 60 & $78 \%$ & C. felis & {$[75]$} \\
\hline & & $20 \%$ & C. canis & \\
\hline & & $2 \%$ & A. erinacei & \\
\hline United Kingdom & 2653 & $12 \%$ & C. felis & [100] \\
\hline & & $<0,1 \%$ & C. canis & \\
\hline & & $<0,1 \%$ & A. erinacei & \\
\hline & & $<0,1 \%$ & P. irritans & \\
\hline & & $<0,1 \%$ & Ca. fasciatus & \\
\hline USA & 11 & $61 \%$ & C. felis & {$[101]$} \\
\hline & & $21 \%$ & C. canis & \\
\hline USA & 100 & $8 \%$ & P. irritans & [102] \\
\hline
\end{tabular}


Unfortunately, studies showing the effect on the prevalence of flea infestation in domestic dog populations have never been conducted. However, in most of the studies cited above, dogs from countries were tested, where repellents are not in use for dogs. Whether in the studies cited from industrialized countries the effect of the use of ectoparasitics since the 1990s had an effect on the rate of flea infestation or whether other factors like improved animal hygiene may be also involved remains speculative.

\section{Fleas of wild canids}

The family Canidae contains the two tribes Vulpini and Canini with a total of 13 genera and 35 species.
However, so far, only few studies have been conducted to examine the flea infestation of wild canids and thus, only limited data are available on the prevalence of fleas and on the species composition of fleas in wild canids. The results of an extended literature search on all 35 canid species yielded only data on flea infestations for six different species (Table 2). Most data are available on fleas on red foxes (Vulpes (V.) vulpes). An Austrian report reviews several studies done in the federal states of Burgenland, Lower Austria and Steiermark in Austria [2]. This review summarized five different studies where fleas were collected from red foxes [3-7]. A total of 13 different flea species were collected from foxes in Austria. The most prevalent species was Chaetopsylla (Ch.)

Table 2 Available data on the prevalence rates of flea infestation in different species of the family Canidae in different countries (A.: Archaepsylla; C.: Ctenocephalides; Ce.: Cediopsylla; Ch.: Chaetopsylla; D.: Dactylopsyllus; E.: Euhoplopsyllus; O.: Oropsylla; Or.: Orchopeas; P.: Pulex; Pa.: Paraceras; R.: Rhopalopsyllus; X. Xenopsylla).

\begin{tabular}{|c|c|c|c|c|}
\hline Canid species & Country & Flea prevalence & Flea species detected & Literature \\
\hline \multirow[t]{12}{*}{ V. vulpes } & Austria & $10-30 \%$ & Ch.globiceps & {$[3-7]$} \\
\hline & & $3-13 \%$ & Ch. trichosa & \\
\hline & & $0.5-20 \%$ & P. irritans & \\
\hline & & $1-2 \%$ & C. felis & \\
\hline & & $1-7 \%$ & C. canis & \\
\hline & Spain & $100 \%$ & P. irritans & [98] \\
\hline & Hungary & $43 \%$ & P. irritans & {$[103]$} \\
\hline & & $37 \%$ & Ch. globiceps & \\
\hline & & $12 \%$ & Ch. trichosa & \\
\hline & & $4 \%$ & Pa. melis & \\
\hline & & $11 \%$ & C. canis & \\
\hline & & $3 \%$ & A. erinacei & \\
\hline \multirow[t]{6}{*}{ V. velox } & U.S.A. & $100 \%$ & P. irritans & {$[9,10]$} \\
\hline & & $92 \%$ & P. simulans & \\
\hline & & $3 \%$ & E. glacialis & \\
\hline & & $<1 \%$ & O. hirsuta & \\
\hline & & $<1 \%$ & E. affinis & \\
\hline & & $<1 \%$ & D. percernis & \\
\hline \multirow[t]{5}{*}{ Urocyon cineroargenteus } & U.S.A. & $38 \%$ & P. simulans & {$[8-10,12]$} \\
\hline & & $<1 \%$ & C. felis & \\
\hline & & $<1 \%$ & C. canis & \\
\hline & & $<1 \%$ & Ce. inequalis interrupta & \\
\hline & & $<1 \%$ & Or. laens & \\
\hline Urocyon littoralis & U.S.A. & $98 \%$ & P. irritans & {$[13]$} \\
\hline \multirow[t]{6}{*}{ Cerdocyon thous } & Brazil & $89 \%$ & Rh. lutzi & [14] \\
\hline & & $7 \%$ & P. irritans & \\
\hline & & $2 \%$ & C. canis & \\
\hline & & $1 \%$ & C. felis & \\
\hline & & $2 \%$ & $x$ cheopis & \\
\hline & Bolivia & $0 \%$ & none & [104] \\
\hline Lycalopex gymnocercus & Bolivia & n.d. & P. irritans & [104] \\
\hline
\end{tabular}


globiceps which was found from 10 to more than $30 \%$ of the foxes tested. Interestingly, the second most prevalent flea species in two of the studies reviewed was the human flea, $P$. irritans. Furthermore, the cat flea and the dog flea were among others found on wild mammals (badger, squirrels, rats, rabbits, chicken, hedgehog). This diverse flea fauna of foxes in Austria may indicate that the red fox may come into contact with different wild and domestic animals potentially used as prey (rodents, rabbits, chicken) or as co-habitation (badger).

A study on the role of Swift foxes ( $V$. velox) for the transmission of plague between prairie dogs in Texas, found that the main flea ectoparasites in these dog population was the human flea ( $P$. irritans) [8]. In six out of ten foxes $P$. simulans was also detected. In one out of ten foxes Oropsylla (O.) hirsuta, a flea of prairie dogs was detected. These data confirmed earlier works of other groups that $P$. irritans is the most prevalent flea species in Swift foxes[9,10]. Two other flea species, Euhoplopsyllus affinis and Dactylopsylla percernis were detected also on foxes in Texas [11]. In a study in Californian gray foxes (Urocyon cinereoargentus) 22/54 foxes (42\%) were found to be infested by fleas [12]. Five different species of fleas were identified. More than $90 \%$ of the fleas found were identified as $P$. simulans. 3\% were classified as C. felis, one percent each as C. canis, Cediopsylla (Ca.) inequalis interrupta and Orchopeas (Or.) laens. A study in a closely related fox species, the island fox (Urocyon littoralis) on the California channel island Santa Cruz, showed that $98 \%$ of all foxes tested were infested by one single flea species, $P$. irritans [13]. In Spain, results of a survey of fleas in carnivorous mammals showed that only $P$. irritans was found on red foxes ( $V$. vulpes). During a leishmaniosis study in the Brazilian State of Bahia, crab-eating foxes (Cerdocyon thous) were studied [14]. All 18 specimen tested were infested with fleas. Five species of fleas were identified. The most frequent species found was Rhopalopsyllus (Rh.) lutzi (89\%), P. irritans (7\%), C. canis (2\%) C. felis (1\%) and Xenopsylla (X.) cheopis (2\%). Probably, fleas parasitizing foxes and other canids may also parasitize domestic dogs in where there is adequate contact between dogs and wild foxes and canids. The summarized data enlarge the number of potential parasitizing flea species on domestic dogs to more than 30 different species.

\section{Fleas as vectors of pathogens}

Beside their role as ectoparasites, the major medical importance of fleas is their role as vectors of various pathogens to humans and animals. While more than 550 arboviruses are found in arthropods, so far surprisingly, no arbovirus has been detected which uses fleas as a biological vector. However, there is some evidence that some viruses, namely feline leukemia virus and myxomatosis virus, under artificial laboratory conditions could be mechanically transmitted by fleas $[15,16]$. The importance of this observation for the natural transmission of these viruses remains to be elucidated.

\section{Plague}

Fleas are mainly the vectors of bacteria. Historically, the most important bacterial agent which is transmitted by fleas is the plague bacterium, Yersinia (Y.) pestis. Human disease caused by $Y$. pestis has been historically associated with rats, mainly with Rattus ( $R a$.) norvegicus and $R a$. rattus. The origin of $Y$. pestis is now thought to be the steppe regions of Central Asia. In nature, the plague agent is transmitted by fleas among the rodent populations. Mainly rodent fleas are involved in the natural transmission, and more than 80 flea species belonging to different genera were found to transmit $Y$. pestis in nature $[17,18]$. These flea species mainly parasitize rodents, but they may be occasionally found on pets and also on dogs which can be shown by the occasional detection of fleas of wild rodents or other wild animals on dogs. The transmission of plague to humans via flea bites is almost exclusively through the oriental rat flea (X. cheopis) which played the major role as bridging vector between the rodent and rat populations and humans.

While the role of cats for the transmission of plague has been established for a long time [19], dogs are considered to be less susceptible to plague and their role for the transmission of $Y$. pestis has not been established equally well. Dogs seem to develop some clinical illness after infection with $Y$. pestis, including symptoms like fever, lethargy and bubos [20]. Epidemiological data show that plague patients are significantly more likely reported for sleeping in the same bed as a dog [21]. These data indicate that probably a long and close contact with dogs and their fleas is necessary for the transmission from dogs to humans [22]. These epidemiological data are strengthened by experimental data, showing that the flea species found most commonly on dogs, the cat flea and the dog flea, are considered to be poor vectors of $Y$. pestis due to their poor ability to become blocked [23]. They may possess a small although not essential importance by their ability to become pestiferous. The mouth parts may be contaminated with $Y$. pestis during blood sucking of bacteriaemic blood. The transmission may occur mechanically or by a newly discovered unblocked transmission mechanism recently shown to play a role in the transmission of plague in the flea species O. montana [24]. However, a role of $P$. irritans, which is found frequently in low prevalence rates on dogs (see above), is under discussion and has not yet been resolved [25]. The role of another flea, occassionally detected on dogs, Echidnophaga (E.) gallinacea, in the transmission of plague is 
unclear, although it is known to become infected with $Y$. pestis [26]. However, it is also thought to be a poor vector for the agent due to its stick-tight behaviour $[23,26]$. The role of Tunga (T.) penetrans as a plague vector is unknown [25]. Possibly the male fleas, which are free hematophagous ectoparasites, may act as pestiferous vectors while the females of $T$. penetrans are not capable to do so, because they are embedded in the host epidermis [27]. No data are available on Archeopsylla erinacei and its potential role as a vector of $Y$. pestis. The ability of $R h$. lutzi to transmit the plague bacterium is unknown. However, a non-identified $R h$. $s p$. is listed as vector in an established wild rodent plague focus in South America [28]. Fleas of the genus Megabothris were also involved in the natural transmission of $Y$. pestis in natural foci in the northwestern U.S.A. [28], while information on species of the genera Ceratopsyllus, Paraceras, Cediopsylla and Ceratophyllus to our best knowledge is not available.

\section{Rickettsioses}

There are mainly two species of rickettsiae which are naturally transmitted by fleas, Rickettsia (R.) typhi, the pathogen of murine typhus and $R$. felis, a recently discovered Rickettsia species causing flea-borne spotted fever.

Murine typhus is a zoonosis which is maintained in nature mainly by a flea-rat-flea transmission cycle [29]. Murine typhus is one of the few rickettsioses which are distributed globally except in the Antarctic [29]. Rats of the genus Rattus, mainly $R$. rattus and $R$. norvegicus are of major importance for the primary transmission cycle as vertebrate hosts. Besides these two species, many other wild and domestic animals may serve as additional vertebrate hosts. Among them, dogs were also found to become infected with $R$. typhi in different areas of the world. In Spain, between 10 to $12 \%$ of dogs showed antibodies against $R$. typhi, while during an outbreak of murine typhus in Austin, Texas, U.S.A., 44\% of dogs tested exhibited antibodies agains $R$. typhi [30-33]. Because of these data, the potential role of pet and stray dogs during urban outbreaks of murine typhus has to be readdressed.

$R$. typhi has deen detected in at least ten species of fleas of the genera Ctenocephalides., Echidnophaga, Leptopsylla, Monopsyllus, Nosopsylla, Pulex and Xenopsylla [29]. Among them is C. felis which is frequently found on dogs all over the world and the most prevalent flea species on dogs in many areas (Table 1). Several other flea species are known to play a role as actual or potential vectors of $R$. typhi, among them are E. gallinacea, $P$. irritans and $X$. cheopis. They are found occasionally on dogs and therefore may support an urban dog-flea-dog transmission cycle (Table 1$). X$. astia, X. bantorum, $X$. brasiliensis, Leptopsylla (L.) segnis and Nosopsylla (N.) fasciatus are primary rodent fleas which may accidentally feed on humans or on dogs [1].

$R$. felis is the pathogen of flea-borne spotted fever. Interestingly, together with $R$. typh $i$, it is the only other Rickettsia species which seems to be globally distributed. Both of these rickettsiae are transmitted by fleas. While the agent of murine typhus has been known for many decades, the agent of flea-borne spotted fever was only detected recently. In 1990, a rickettsia-like organism in an adult flea colony in the Elward Laboratory, Maryland was detected and named "ELB agent" [34]. Later, the further characterization of this agent resulted in the classification as a spotted fever group rickettsiae [35]. In recent years, the widespread geographical distribution of $R$. felis and of the disease caused by this agent increased, indicating that $R$. felis is the most widely distributed Rickettsia species.

The cat flea ( $C$. felis) was identified as the primary vector and reservoir of $R$. felis. So far, this Rickettsia species has been detected in more than 30 countries on five continents except Antarctica [36-41]. The reason for this almost universal distribution may be seen in the global distribution of $C$. felis which finally transported its ectoparasites and their endoparasites into all parts of the world. The high infection rates of colonized cat flea populations from 40 up to $90 \%$ [42], together with experimental data, imply that $R$. felis is well-adapted to its vector including transstadial and transovarial transmission leading to the high infection rates of fleas $[43,44]$. Although the cat flea is thought to be most important as a vector, $R$. felis was detected in at least eleven other flea species [36]. Among them are P. irritans, Archaeopsylla (A.) erinacei, E. gallinacea, C. canis, $T$. penetrans and $X$. cheopis. These species are found either sporadically or more frequently also on dogs.

Although a number of serological studies have been conducted to identify the mammalian host(s) of R. felis, no definitive mammalian host has been identified so far. Among the peri-domestic mammals which exhibit antibodies against $R$. felis, cats, dogs and opossums are found [36]. Cats are believed to be the most important hosts for the cat flea and for the rickettsiae transmitted by cat fleas. In different areas of the world antibody seroprevalence rates of 4 to $100 \%$ of cats were reported in several studies (summarized in [36]). However, the definitive role of the cat as a mammalian host supporting the life cycle of $R$. felis, has not been established. While the transmission of fleas to cats had been proven either by serology or by molecular biology [44], the horizontal transmission of $R$. felis from mammals to fleas so far has not been shown [45]. Therefore, the role of cats for the life cycle of $R$. felis remains unclear. Even more unclear is the role of domestic dogs for the maintainance of the natural life cycle of $R$. felis. Only few 
seroprevalence studies in dogs are available. In Spain, $16 \%$ of dogs showed specific antibodies against $R$. felis [31]. Two other reports indicate an association of PCRpositive dogs to the occurance of sporadic human cases of flea-borne spotted fever. In Germany and in Spain, $R$. felis-infected dogs were present in families with human cases $[46,47]$. The dog seems to play the role as a transport vehicle for C. felis and also for its parasite, R. felis to humans. So far, no wild animal reservoir of $R$. felis has been detected. There is, however, some evidence, that the opossum (Didelphis virginiana) may play a role $[48,49]$.

Another Rickettsia species was recently found in fleas. In the USA, a sylvatic transmission cycle of $R$. prowazekii was detected [50]. When exploring this transmission cycle, $R$. prowazekii could be detected in lice and in squirrel fleas (Or. howardi). The exact transmission between the squirrels and from squirrels to humans remains unclear. However, it is hypothesized that R. prowazekii is excreted by the fleas (and lice) with their feces. After drying of feces, the pathogen may be inhaled as aerosol and then may cause typhus. A role for dogs within this so-called sylvatic transmission has not been postulated so far. However, dogs may serve as mechanical carriers of fleas from outside to the home and therefore serve as a bridging host.

\section{Bartonellosis}

The third group of bacterial pathogens transmitted by fleas are members of the genus Bartonella. Among the more than 20 species of Bartonella, at least eleven species are known to cause human disease [51,52]. Bartonella (B.) henselae and B. clarridgeiae are transmitted by fleas and they cause a disease in humans, cat-scratch disease. Dogs may be either the primary reservoir or the accidental hosts for at least seven Bartonella species ( $B$. vinsonii subsp. berghoffii, $B$. quintana, $B$. henselae, $B$. clarridgeiae, B. washoensis, B. elizabethae, B. koehlerae) [53]. Epidemiological data, however, indicate that dogs are accidental hosts rather than reservoir hosts [51]. $B$. henselae and $B$. clarridgeiae are the two species which are mainly detected in fleas from dogs. They so far have been detected in four continents (Table 3).

Besides these two pathogens of the genus Bartonella, dogs and canids seem to play a role as putative natural hosts for B. vinsonii subsp. berkhoffii [54-56]. Various data show that stray dogs in the tropics exhibit high antibody prevalence rates against $B$. vinsonii subsp. berkhoffii. In sub-Saharan Africa and in Asia 26\% to 65\% of domestic dogs tested were antibody positive against this species $[57,58]$. In contrast, dogs in non-tropical regions (Europa, U.S.A., northern Africa) were seropositive only in $<5 \%[52,59,60]$. However, in California, B. vinsonii subsp. berkhoffii was detected by serology in up to $35 \%$ and in $28 \%$ by PCR in coyotes (Canis latrans). This high prevalence and the apparent chronic bacteriaemia imply a role of the coyote as natural host for B. vinsonii subsp. berkhoffii [59]. Possibly, the frequent contacts of stray dogs with wild canids cause the high prevalence rates while the contacts of domestic dogs with coyotes in California seem to be limited. B. vinsonii subsp. berkhoffii has also been incriminated as a cause of human heart disease [61]. The infection of humans by fleaborne bartonellae mainly occurs via cat scratches. An infection of cats via infected fleas could be experimentally demonstrated, although this way is thought not to play a major role in the transmission and epidemiology

Table 3 Detection of Bartonella spp. in fleas collected from dogs from different countries (A. Archaeopsylla; C.: Ctenocephalides; Ce.: Ceratopsyllus)

\begin{tabular}{|c|c|c|c|c|c|}
\hline Country & $\begin{array}{l}\text { Dogs } \\
\text { tested }\end{array}$ & $\begin{array}{l}\text { Flea species tested for } \\
\text { Bartonella }\end{array}$ & $\begin{array}{l}\text { No of fleas } \\
\text { tested }\end{array}$ & $\begin{array}{l}\text { No of fleas positive for Bartonella (B.) } \\
\text { species: }\end{array}$ & Literature \\
\hline France & 84 & C. felis, C. canis, P. irritans & 317 & $\begin{array}{l}\text { B. henselae } 2 \\
\text { B. clarridgeiae } 12\end{array}$ & {$[53]$} \\
\hline \multirow[t]{4}{*}{ Germany } & 49 & C. felis & 114 & $\begin{array}{l}\text { B. henselae } 0 \\
\text { B. clarridgeiae } 0\end{array}$ & {$[53]$} \\
\hline & & C. canis & 4 & $\begin{array}{l}\text { B. henselae } 0 \\
\text { B. clarridgeiae } 0\end{array}$ & \\
\hline & & A. erinacei & 26 & $\begin{array}{l}\text { B. henselae } 0 \\
\text { B. clarridgeiae } 0\end{array}$ & \\
\hline & & Ce. gallinae & 2 & $\begin{array}{l}\text { B. henselae } 0 \\
\text { B. clarridgeiae } 0\end{array}$ & \\
\hline Laos & 3 & C. felis & 23 & B. clarridgeiae 1 & [39] \\
\hline Lebanon & 2 & C. canis & 50 & $\begin{array}{l}\text { B. henselae } 0 \\
\text { B. clarridgeiae } 0\end{array}$ & {$[37]$} \\
\hline New Caledonia & 8 & C. felis & 20 & B. clarridgeiae 1 & {$[38]$} \\
\hline $\begin{array}{l}\text { United } \\
\text { Kingdom }\end{array}$ & 31 & C. felis & 280 & B. henselae 0 & {$[16]$} \\
\hline
\end{tabular}


of flea-borne Bartonella. The infection of humans via fleas seems possible, however this mode of infection also does not seem to play a major role for the epidemiology of Bartonella. Sporadic cases of transmission of bartonellae by dog scratches or dog bites document the potential risk of transmission from dog to human and therefore may also involve dogs as bridging hosts from animals to humans [62,63].

\section{Miscellaneous}

A number of other bacterial pathogens have been isolated from fleas. These are Coxiella burnetii, Francisella tularensis, Staphylococcus aureus, Salmonella enteritidis, Borrelia burgdorferi, Borrelia duttoni, Listeria monocytogenes, Y. pseudotuberculosis, Erysipelothrix rhusiopathiae, Burkholderia (Bu.) mallei, Bu. pseudomallei, and Brucella abortus [1]. Probably, most of these pathogens were detected by chance after a bacteriaemic bloodmeal. The potential to serve as vectors for the agents listed, although unknown and never tested experimentally, seems to be minimal.

\section{Fleas as intermediate hosts of parasites}

Fleas play an important role as intermittent hosts in the development of at least three species of tapeworms. The double-pored tapeworm (Dipylidium caninum) is dependent on fleas as intermediate hosts and on dogs as final hosts. It is the most prevalent tapeworm in dogs and occurs world-wide. Prevalence data are not available for most parts of the world. In central Europe the carrier rate of dogs ranges from 0.5 to $6 \%$ in Austria and Poland to more than 65\% in Albania [64-67]. In Mexico, the prevalence rate reached almost 50\% [68]. The adult tapeworms in the small intestine produce proglottids which are passed in the feces. After desiccation in air, the eggs are expelled form the proglottids and then they can be digested by flea larvae due to their chewing mandibles, but not by adult fleas. The eggs develop rapidly into flea pupae. The development is completed if the adult flea is accidentally ingested by humans or by dogs and cats. There, the adult worm is liberated from the cysticercoid and attaches to the gut of the new host. The cat flea ( $C$. felis), the dog flea (C. canis) and the human flea ( $P$. irritans) play a major role in the life cycle of this tapeworm. In Africa, the warthog flea ( $E$. larina) was found to be responsible in some cases for the infection of domestic dogs [1]. Mainly children are at risk when playing with infected pets due to their close contacts with the animals and the low personal hygiene standards. Two other tapeworms, the dwarf tapeworm (Rodentolepis nana, syn. Hymenolepis (H.) nana) and the rodent tapeworm (H. diminuta) use fleas and other insects as intermediate hosts for their development from eggs to cysticercoids. For these worms, humans may play a role as accidental final hosts. Humans are infected by incidental ingestion of infected rat fleas (X. cheopis, $N$. fasciatus) and they may play a role as accidental final hosts. One other worm, the microfilaria Acanthocheilonema (Dipetalonema) reconditum is known to be transmitted by cat fleas to humans and to dogs [69]. Dogs and humans seem to form aberrant hosts for this microfilaria species which may cause severe eye disease and inflammatory skin disease also [69].

\section{Fleas as ectoparasites of dogs}

Several species of fleas may pose a threat as ectoparasites for humans and pet animals. From a total of ten species of fleas of the genus Tunga, T. penetrans is the only species which may be found on dogs and humans. A second species, T. triamillata, may be found on humans, but so far has not been detected on dogs [70]. $T$. penetrans is known to occur mainly in southern and Central America and in Africa. The females of the sand flea penetrate the skin of the host to the basal layer of the corium [71]. There, they feed on blood and tissue exsudates produced by the host's inflammatory response. Only female fleas cause tungiasis. The infestation of the skin may cause severe damage by inflammatory response or by bacterial superinfection. Dogs are commonly infested and especially the snout and the pads of the feet may be involved. Infestations of humans or animals occurs if adult females which developed in the soil from larvae to pupae and to imagos which then may come into contact with the skin of suitable vertebrate hosts. Penetration of the skin occurs within minutes. Within 7 to 14 days, the females increase in size up to $10 \mathrm{~mm}$ and they produce up to 200 eggs which are expelled. If conditions are favourable, larvae will hatch and develop to pupae and imagos again. In tungiasis, dogs may play a role as vertebrate hosts of the flea and as a bridging host, importing the fleas into the surroundings of houses or into houses where they may complete their life cycle and subsequently infest humans.

Although not in the scope of this review, which is concentrating mainly on the role of dogs and wild canids as hosts for fleas and flea-transmitted diseases, the importance of domestic cats for the maintenance and transmission of fleas and flea-borne diseases should be mentioned. Several studies in different countries testing for or comparing the infestion of fleas on dogs and cats clearly show that domestic cats have similar or higher infestation rates with fleas than dogs [41,72-75]. These limited studies also underscore the great importance of cats as animal bridging hosts for the transmission of fleas (mainly C. felis) to humans. 


\section{Conclusions}

Dogs and their ectoparasites of the order Siphonaptera play major, but different roles as vectors or hosts of pathogens. Among the diseases transmitted by fleas, the historically most important disease of mankind, plague, is of special importance. Among the rickettsioses transmitted by fleas, one human disease, murine typhus, was characterized in the early 1900 s while flea-borne spotted fever is a disease which has been recognized only since 1990. Flea-transmitted Rickettsia species are the only rickettsiae which are globally distributed. Fleas may directly ingest the pathogens into the host during their blood meals or pathogens are excreted with the fleas' feces and will then be inoculated by scratching. Also, direct injection during the blood-feeding of flees seems possible. More recently, the role of fleas and dogs for the epidemiology and epizootology of several Bartonella species was detected. The role of fleas as intermediate hosts for the developmental cycle of tapeworms is recognized and may be of medical importance in situations with low personal hygiene standards. Finally, fleas occur as ectoparasites on dogs and also on humans, and tungiasis may cause severe skin infections. In the future more pathogens may be detected which are in some way of transmission or development associated with fleas.

\section{Author details}

${ }^{1}$ Bundeswehr Institute of Microbiology, Department of Virology and Rickettsiology, Neuherbergstrasse 11, D-80937 Munich, Germany. ${ }^{2}$ Institute of Animal Hygiene and Public Veterinary Medicine, University of Leipzig, An den Tierkliniken 1, D-04103 Leipzig, Germany.

\section{Authors' contributions}

Both authors contributed equally to this publication and have approved the final version of the manuscript

\section{Competing interests}

Both authors declare that they do not have any financial competing interests (political, personal, religious, ideological, academic, intellectual, commercial or any other) in relation to this manuscript.

Received: 1 March 2011 Accepted: 18 July 2011 Published: 18 July 2011

\section{References}

1. Durden LA, Hinkle NC: Fleas (Siphonaptera). In Medical and Veterinary Entomology.. 2 edition. Edited by: Mullen GR, Durden LA. Academic Press, San Diego, USA; 2009:115-136.

2. Prosl H, Lassnig H, Mramor C: Zur Siphonaptera-Fauna des Rotfuchses (Vulpes vulpes) in Österreich. Denisia 2004, 13:493-489.

3. Hinaidy HK: Die Parasitenfauna des Rotfuchses, Vulpes vulpes (L.), Österreich. Z Vet Med B 1971, 18:21-32.

4. Hinaidy HK: Ein weiterer Beitrag zur Parasitenfauna des Rotfuchses, Vulpes vulpes (L.), Österreich. Z Vet Med B 1976, 23:66-73.

5. Lassnig H, Prosl H, Hinterdorfer F: Zur Parasitenfauna des Rotfuchses (Vulpes vulpes) in der Steiermark. Wien Tieräztl Mschr 1998, 85:116-122.

6. Ressl F: Die Siphonapterenfauna des Verwaltungsbezirks Scheibbs (Niederösterreich). Z Parasitenk 1963, 23:470-490.

7. Prosl H, Heid K, Mramor C, Lassnig H: Zur Ektoparasitenfauna des Rotfuchses (Vulpes vulpes) in Ostösterreich. Entomol Austriaca 2001, 2:9-10.
8. McGee BK, Butler MJ, Pence DB, Alexander JL, Nissen JB, Ballard WB, Nicholson KL: Possible vector dissemination by Swift foxes following a plague epizootic in black-tailed prairie dogs in Northwestern Texas. J Wildlife Dis 2006, 42:415-420.

9. Kilgore DL: An ecological study of the Swift fox (Vulpes velox) in the Oklahoma Panhandle. The American Midland Naturalist 1969, 81:512-534.

10. Miller DS, Campbell BG, McLean RG, Campos E, Covell DF: Parasites of Swift fox (Vulpes velox) from southeastern Colorado. The Southwestern Naturalist 1998, 43:476-479.

11. Pence DB, Kamler JF, Ballard WB: Ectoparasites of the Swift fox in Northwestern Texas. J Wildlife Dis 2004, 40:543-547.

12. Gabriel MW, Henn J, Foley JE, Brown RN, Kasten RW, Foley P, Chomel BB: Zoonotic Bartonella species in fleas collected on gray foxes (Urocyon cinereoargenteus). Vector Borne Zoonotic Dis 2009, 9:597-602.

13. Crooks KR, Scott CA, Angeloni L, Bowen L, Kimsey RB, Van Vuren DH: Ectoparasites of the island fox on Santa Cruz Island. J Wildlife Dis 2001, 37:189-193.

14. Cerqueira EJL, Silva EM, Monte-Alegre AF, Sherlock IA: Consideracoes sobre pulgas (Siphonaptera) da raposa Cerdocyon thous (Canisae) da area endemica de leishmaniose visceral de Jacobina, Bahiam Brasil. Rev Soc Bras Med Trop 2000, 33:91-93.

15. Vobis M, D'Haese J, Mehlhorn H, Mencke N: Evidence of horizontal transmission of feline leukemia virus by the cat flea (Ctenocephalides felis). Parasitol Res 2003, 91:467-470

16. Shaw SE, Kenny MJ, Tasker S, Birtles RJ: Pathogen carriage by the cat flea Ctenocephalides felis (Bouché) in the United Kingdom. Vet Microbiol 2004, 102:183-188.

17. Pollitzer R: A review of recent literature on plague. Bull World Health Organ 1960, 23:313-400.

18. Anisimov AP, Lindler LE, Pier GB: Intraspecific diversity of Yersinia pestis. Clin Microbiol Rev 2004, 17:434-464.

19. Gage KL, Dennis DT, Orloski KA, Ettestad P, Brown TL, Reynolds PJ, Pape PJ, Fritz CL, Carter LG, Stein JD: Cases of cat -associated human plague in the Western US, 1977-1998. Clin Infect Dis 2000, 30:893-900.

20. Dennis DT, (ed): Plague Manual: Epidemiology, distribution Surveillance and control. World Health Organization, Geneva, Switzerland; 1999.

21. Chomel BB, Ben S: Zoonoses in the bedroom. Emerg Infect Dis 2011, 17:167-172.

22. Gould LH, Pape J, Ettestad P, Griffith KS, Mead PS: Dog-associated risk factors for human plaque. Zoonoses Public Health 2008, 55:448-454.

23. Burroughs AL: Sylvatic plague studies. The vector efficacy of nine species of fleas compared with Xenopsylla cheopis. J Hyg (Lond) 1947, 45:371-396.

24. Eisen RJ, Bearden SW, Wilder AP, Montenieri JA, Antolin MF, Gage KL: Earlyphase transmission of Yersinia pestis by unblocked fleas as a mechanism of explained rapidly spreading plague epizootics. Proc Natl Acad Sci USA 2006, 103:15380-15385.

25. Laudisoit A, Leirs H, Makundi RH, Van Dongen S, Davis S, Neerinckx S, Deckers J, Libois R: Plague and the human flea in Tanzania. Emerg Infect Dis 2007, 13:687-693.

26. Wheeler C, Douglas J, Evans F: The role of burrowing owl and the sticktight flea in the spread of plague. Science 1941, 94:560-561.

27. Witt LH, Linardi PM, Meckes O: Blood-feeding of Tunga penetrans. Med Vet Entomol 2004, 18:439-441.

28. Manson-Bahr PEC, Apted FIC: Manson's Tropical Diseases. In Plague and Melioidosis. Volume Chapter 20.. 18 edition. Ballière Tindall, London, United Kingdom; 1982:331-347.

29. Azad AF: Epidemiology of murine typhus. Annu Rev Entomol 1990, 35:553-569.

30. Azad AF, Radulovic S, Higgins JA: Flea-borne rickettsioses: ecologic considerations. Emerg Infect Dis 1997, 3:319-327.

31. Nogueras MM, Pons I, Ortuno A, Segura F: Seroprevalence of Rickettsia typhi and Rickettsia felis in dogs from north-eastern Spain. CMI 2008, 15(suppl 2):237-238.

32. Lledo L, Gegundez I, Serrano JL, Saz JV, Beltran M: A sero-epidemiologcal study of Rickettsia typhi infection in dogs in Soria province, Central Spain. Ann Trop Med Parasitol 2003, 197:861-864.

33. Adjemian J, Parks S, McElroy K, Campbell J, Eremeeva ME, Nicholson W, McQuiston J, Taylor J: Murine typhus in Austin, Texas, USA, 2008. Emerg Infect Dis 2010, 16:412-417. 
34. Adams JR, Schmidtmann ET, Azad AF: Infection of colonized cat fleas (Ctenocephalides felis) with a rickettsia-like organism. Am J Trop Med Hyg 1990, 43:400-409.

35. Bouyer DH, Stenos J, Crocquet-Valdes P, Moron CG, Popov VL, ZavalaVelazquez JE, Foil LD, Stothard DR, Azad AF, Walker DH: Rickettsia felis: molecular characterization of a new member of of the spotted fever group. Int J Syst Evol Microbiol 2001, 51:339-347.

36. Reif KE, Macaluso KR: Ecology of Rickettsia felis: A review. J Med Entomol 2009, 46:723-736.

37. Mba PA, Marié J-L, Rolain J-M, Davoust B, Beaucoumu J-C, Raoult D, Parola D: Rickettsia felis and Bartonella henselae in fleas from Libanon. Vector-borne Zoonotic Dis 2011.

38. Mediannikov O, Cabre O, Qu F, Socolovschi C, Davoust B, Marié JL, Parola P, Raoult D: Rickettsia felis and Bartonella clarridgeiae in fleas from New Caledonia. Vector-borne Zoonotic Dis 2011.

39. Varagnol M, Parola P, Jouan R, Beaucournu JC, Rolain jM, Raoult D: First detection of Rickettsia felis and Bartonella clarridgeiae in fleas from Laos. Clin Microbiol Infect 2009, 15(suppl 2):334-335.

40. Maioli G, Horta MC, Ogrzewalska M, Capelli G, Souza SO, Richtzenhain LJ, Labruna MB: First detection of Rickettsia felis in Ctenocephalides felis fleas from Italy. Clin Microbiol Infect 2009, 15(suppl 2):222-223.

41. Capelli G, Montarsi F, Porcellato E, Maioli G, Furnari C, Rinaldi L, Oliva G, Otranto D: Occurance of Rickettsia felis in dog and cat fleas (Ctenocephalides felis) from Italy. Parasit Vectors 2009, 2(suppl 1):S8

42. Higgins JA, Sacci JB Jr, Schriefer ME, Endris RG, Azad AF: Molecular identification of rickettsia-like microorganisms associated with colonized cat fleas (Ctenocephalides felis). Insect Mol Biol 1994, 3:27-33.

43. Azad AF, Sacci JB Jr, Nelson WM, Dasch GA, Schmidtmann Et, Carl M: Genetic characterization and transovarial transmission of a typhus-like rickettsia found in cat fleas. Proc Natl Acad Sci USA 1992, 89:43-46.

44. Wedicamp J Jr, Foil LD: Vertical transmission of Rickettsia felis in the cat flea (Ctenocephalides felis Bouche). J Vector Ecol 2002, 27:96-101.

45. Weinert LA, Werren JH, Aebi A, Stone GN, Jiggins FM: Evolution and diversity of Rickettsia bacteria. BMC Biol 2009, 7:6.

46. Oteo JA, Portillo O, Santibanez S, Blanco JR, Perez-Martinez L, Ibarra V: Cluster of cases of human Rickettsia felis infection from Southern Europe (Spain) diagnosed by PCR. J Clin Microbiol 2006, 44:2669-2671.

47. Richter J, Fournier PE, Petridou J, Häussinger D, Raoult D: Rickettsia felis infection acquired in Europe and documented by polymerase chain reaction. Emerg Infect Dis 2002, 8:207-208.

48. Boostrom A, Beier MS, Macaluso JA, Macaluso KR, Sprenger D, Hayes J, Radulovic S, Azad AF: Geographic association of Rickettsia felis-infected oppossums with human murine typhus, Texas. Emerg Infect Dis 2007, 8:549-554.

49. Schriefer ME, Sacci JB Jr, Taylor JP, Higgins JA, Azad AF: Murine typhus: updated role of multiple urban components and a second typhus-like rickettsia. J Med Entomol 1994, 31:681-685.

50. Bozeman FM, Masiello SA, Williams MS, Elisberg BL: Epidemic typhus rickettsiae isolated from flying squirrels. Nature 1975, 255:545-547.

51. Chomel BB, Boulouis S, Maruyama S, Breitschwerdt EB: Cat scratch disease and other zoonotic Bartonella infections. J Am Vet Med Assoc 2006, 224:1270-1279.

52. Chomel BB, Boulouis S, Maruyama S, Breitschwerdt EB: Bartonella spp. in pets and effect on human health. Emerg Infect Dis 2006, 12:389-394.

53. Just FT, Gilles J, Pradel I, Pfalzer S, Lengauer H, Hellmann K, Pfister K: Molecular evidence for Bartonella spp. in cat and dog fleas from Germany and France. Zoonoses Public Health 2008, 55:514-520.

54. Kordick DL, Breitschwerdt EB: Persistent infection of pets within a household with three Bartonella species. Emerg Infect Dis 1998, 4:325-328.

55. Breitschwerdt EB, Atkins CE, Brown TT, Kordick DL, Snyder PS: Bartonella vinsonii subsp. Berkhoffii and related members of the alpha subdivision of the Proteobacteria in dogs with cardiac arrhythmias, endocarditis or myocarditis. J Clin Microbiol 1999, 37:3618-3626.

56. Breitschwerdt EB, Kordick DL: Bartonella infection in animals: carriership, reservoir potential, pathogenicity, and zoonotic potential for human infection. Clin Microbiol Rev 2000, 13:428-438.

57. Henn JB, VanHorn BA, Kasten RW, Kachani M, Chomel BB: Antibodies to Bartonella vinsonii subsp. Berkhoffii in Moroccan dogs. Am J Trop Med Hyg 2006, 74:222-223.

58. Muller S, Boulouis HJ, Viallard J, Beugnet F: Epidemiological survey of canine bartonellosis to Bartonella vinsonii subsp. berkhoffii and canine monocytic ehrlichiosis in dogs on the island of Reunion. Rev Med Vet 2004, 155:377-380.

59. Boulouis HJ, Chang CC, Henn JB, Kaszten RW, Chomel BB: Factors associated with the rapid emergence of zoonotic Bartonella infections. Vet Res 2005, 36:383-410.

60. Kernif T, Aissi M, Doumandji s-E, Chomel BB, Raoult D, Bitan I: Molecular evidence of Bartonella infection in domestic dogs from Algeria, Northern Africa, by polymerase chain reaction (PCR). Am J Trop Med Hyg 2010, 83:298-300.

61. Chomel BB, Kasten RW, Williams C, Wey AC, Henn JB, Maggi R, Carrasco S, Boulouis HJ, Maillard R, Breitschwerdt EB: Bartonella endocarditis: a pathology shared by animals reservoirs and patients. Ann N Y Acad Sci 2009, 1166:120-126.

62. Keret $D$, Giladi M, Kletter $Y$, Wietroub S: Cat scratch disease osteomyelitis from a dog scratch. J Bone Joint Surg Br 1998, 80-B:766-767.

63. Tsukahara M, Tsuneoka H, Lino H, Ohno K, Murano I: Bartonella henselae infection from a dog. Lancet 1998, 352:1682.

64. Supperer R, Wenzel B: Zum Endoparasitenbefall von Stadt- und Landhunden. Wien Tierärztl Monatsschr 1967, 54:182-185.

65. Supperer R, Hinaidy HK: Ein Beitrag zum Parasitenbefall der Hunde und Katzen in Österreich. Dtsch Tierätztl Wschr 1986, 93:383-386.

66. Xhaxhiu D, Kusi I, Rapti D, Kondi E, Postoli R, Rinaldi L, Dimitrova ZM, Visser M, Knaus M, Rehbein S: Principal intestinal parasites of dogs in Tirana, Albania. Parasitol Res 2011, 108:341-353.

67. Tylkowska A, Pilarczyk B, Gregorzczyk A, Templin E: Gastrointestinal helminths of dogs in Western Pommerania, Poland. Wlad Parazytol 2010, 56:269-276.

68. Canto GJ, Garcia MP, Garcia A, Guerrero MJ, Mosqueda J: The prevalence and abundance of helminthic parasites in stray dogs from the city of Queretaro in central Mexico. J Helminthol 2010, 20:1-7.

69. Otranto D, Eberhard ML: Zoonotic helminths affecting the human eye. Parasit Vectors 2010, 4:41.

70. Pampiglione S, Fioravanti ML, Gustinelli A, Onore G, Mantovani B, Luchetti A, Trentini M: Sand flea (Tunga spp.) infections in humans and in animals. State of the art. Med Vet Entomol 2009, 23:172-186.

71. Eisele M, Heukelbach J, van Marck E, Mehlhorn H, Meckes O, Franck S, Feldmeier $\mathrm{H}$ : Investigations on the biology, epidemiology, pathology and control of Tunga penetrans in Brazil. I. Natural history of tungiasis in man. Parasitol Res 2003, 90:87-99.

72. Farkas R, Gyurkovszky M, Solymosi N, Beugnet F: Prevalence of fleas infestation in dogs and cats in Hungary combined with a survey of owner awareness. Med Vet Entomol 2009, 23:187-194.

73. Beck W, Boch K, Mackensen H, Wiegand B, Pfister K: Qualitative and quantitative observations on the flea population dynamics of dogs and cats in several areas of Germany. Vet Parasitol 2006, 137:130-136.

74. Koutinas AF, Papazahariadou MG, Rallis TS, Tzivara NH, Himonas CA: Flea species from dogs and cats in northern Greece: environmental and clinical implications. Vet Parasitol 1995, 58:109-115.

75. Bond R, Riddle A, Mottram L, Beugnet F, Stevenson R: Survey of flea infestation in dogs and cats in the United Kingdom during 2005. Vet Rec 2007, 160:503-506.

76. Xhaxhiu D, Kusi I, Rapti D, Visser M, Kaus M, Lindner T, Rehbein S: Ectoparasites of dogs and cats in Albania. Parasitol Res 2009, 105:1577-1587.

77. Gonzalez A, Castro DdC, Gonzalez S: Ectoparasitic species from Canis familiaris (Linné) in Buenos Aires province, Argentina. Vet Parasitol 2004, 120:123-129.

78. Schloderer D, Owen H, Clark P, Stenos J, Fenwick SG: Rickettsia felis in fleas, Western Australia. Emerg Infect Dis 2006, 12:841-843.

79. Pilger D, Schwalfenberg S, Heukelbach J, Mehlhorn H, Mencke N, Khakban A, Feldmeier H: Investigations on the biology, epidemiology, pathology, and control of Tunga penetrans in Brazil: VII. The importance of animal reservoirs for human disease. Parasitol Res 2008, 102:875-880.

80. Rodrigues DF, Daemon E, Rodrigues AF: Characterization of ectoparasites on dogs in the nucleus of urban expansion of Juiz de fora, Minas Gerais, Brazil. Rev Bras Parasitol Vet 2008, 17:185-188.

81. Dantes-Torres F, Melo MF, Figueredo LA, Brandao-Filho SP: Ectoparasite infestation on rural dogs in the municipality of Sao Vicente Férrer, Pernambuco, Northeastern Brazil. Rev Bras Parasitol Vet 2009, 18:75-77. 
82. Klimpel S, Heukelbach J, Pothmann D, Rückeret S: Gastrointestinal and ectoparasites from urban stray dogs in Fortaleza (Brazil): high infection risk for humans? Parasitol Res 2010, 107:713-719.

83. Alcaino HA, Gorman TR, Alcaino R: Flea species from dogs in three cities in Chile. Vet Parasitol 2002, 105:261-265.

84. Haarlov N, Kristensen S: Beiträge zur Dermatologie von Hund und Katze. 3. Flöhe von Hunden und Katzen in Dänemark. Tierärztl Praxis 1977, 5:507-511.

85. Franc $M$, Choquart $P$, Cadiergues MC: Species of fleas found on dogs in France. Rev Med Vet 1998, 149:135-140.

86. Müller J, Kutschmann K: Flohnachweise auf Hunden im Einzugsgebiet der Magdeburger Poliklinik für kleine Haus- und Zootiere. Angew Parasitol 1985, 26:197-203.

87. Kalvelage H, Münster M: Die Ctenocephalides canis und Ctenocephalides felis-Infestation von Hund und Katze. Tierärztl Praxis 1991, 19:200-206.

88. Tavassoli M, Ahmadi A, Imani A, Ahmadiara E, Javadi S, Hadian M: Survey of flea infestation in dogs in different geographic regions of Iran. Korean J Parasitol 2010, 48:145-149.

89. Wall R, Shaw SE, Penaliggon J: The prevalence of flea species on cats and dogs in Ireland. Med Vet Entomol 1997, 11:404-406.

90. Rinaldi L, Spera G, Musella V, Carbone S, Veneziano V, lori A, Cringoli G: A survey of fleas on dogs in southern Italy. Vet Parasitol 2007, 148:375-378

91. Chee JH, Kwon JK, Cho HS, Cho KO, Lee YJ, Abd El-Aty AM, Shin SS: A survey of ectoparasite infestations in stray dogs in Gwan-ju City, Republic of Korea. Korean J Parasitol 2008, 46:23-27.

92. Varagnol M, Parola P, Jouan R, Beaucournu J-C, Rolain j-M, Raoult D: First detection of Rickettsia felis and Bartonella clarridgeiae in fleas from Laos. Clin Microbiol Infect 2009, 15(suppl 2):334-335.

93. Cruz-Vazquez C, Gamez CE, Fernandez PM, Para RM: Seasonal occurance of Ctenocephalides felis felis and Ctenocephalides canis (Siphonaptera Pulicidae) infesting dogs and cats in an urban area in Cuernavaca, Mexico. J Med Entomol 2001, 38:111-113.

94. Ugbomoiko US, Ariza L, Heukelbach J: Parasites of importance for human health in Nigerian dogs: high prevalence and limited knowledge of pet owners. BMC Vet Res 2008, 4:49.

95. Anjo AG, Omani KT, Rajput Zl: Ctenocephalides felis in dogs and cats in Tandojam region. Pak J Biol Sci 2007, 10:2579-2582.

96. Rudzinska M, Sulgostowska T: Parasitic fleas in dogs from two Warsaw shelters, urban and suburban. Wiad Parazytol 1996, 42:229-234.

97. Gracia MJ, Lucientes J, Castillo JA, Peribanez MA, Latorre E, Zarate J, Arbea I: Pulex irritans infestation in dogs. Vet Rec 2000, 147:748-749.

98. Marquez FJ, Millan J, Rodriguez-Liebana JJ, Garcia-Egea I, Muniain MA: Detection and identification of Bartonella sp. in fleas from carnivorous mammals in Andalusia, Spain. Med Vet Entomol 2009, 23:393-398.

99. Gracia MJ, Calvete C, Estrada R, Castillo JA, Peribanez MA, Lucientes J: Fleas parasitizing domestic dogs in Spain. Vet Parasitol 2008, 151:312-319.

100. Chesney CJ: Species of flea found on cats and dogs in southwest England: further evidence of their polyxenous state and implications for flea control. Vet Rec 1995, 136:356-358.

101. Durden LA, Judy TN, Martin JE, Spedding LS: Fleas parasitizing domestic dogs in Georgia, USA: species composition and seasonal abundance. Vet Parasitol 2005, 130:157-162.

102. Harman DW, Halliwell RE, Greiner EC: Flea species from dogs and cats in north-central Florida. Vet Parasitol 1987, 23:135-140.

103. Sreter T, Szell Z, Varga I: Ectoparasite infestations of red foxes (Vulpes vulpes) in Hungary. Vet. Parasitol 2003, 115:349-354

104. Fiorello CV, Robbins RG, Maffei L, Wade SE: Parasites of free-ranging small canids and felids in the Bolivian Chaco. J Zoo Wildl Med 2006, 37:130-134.

doi:10.1186/1756-3305-4-139

Cite this article as: Dobler and Pfeffer: Fleas as parasites of the family

Canidae. Parasites \& Vectors 2011 4:139

\section{Submit your next manuscript to BioMed Central and take full advantage of:}

- Convenient online submission

- Thorough peer review

- No space constraints or color figure charges

- Immediate publication on acceptance

- Inclusion in PubMed, CAS, Scopus and Google Scholar

- Research which is freely available for redistribution 